\title{
Preparation and evaluation of strawberry and date blended juice ready to serve drink
}

\author{
Mohsin Khalid ${ }^{1}$, Muhammad Muneeb ${ }^{1 *}$, Baber Shamrez ${ }^{2}$, Ali \\ Muhammad $^{1}$, Muhammad Ayub ${ }^{1}$, Yasser Durrani ${ }^{1}$ and Syed Awais Ali ${ }^{1}$ \\ 1. Department of Food Science and Technology, Faculty of Nutrition Sciences, The University of Agriculture, \\ Peshawar-Pakistan \\ 2. Research station Abbottabad, Hazara, Kyhber Pakhtunkhwa-Pakistan \\ *Corresponding author's email: mmktk@aup.edu.pk
}

Citation

Mohsin Khalid, Muhammad Muneeb, Baber Shamrez, Ali Muhammad, Muhammad Ayub, Yasser Durrani and Syed Awais Ali. Preparation and evaluation of strawberry and date blended juice ready to serve drink. Pure and Applied Biology. Vol. 8, Issue 4, pp2228-2237. http://dx.doi.org/10.19045/bspab.2019.80168

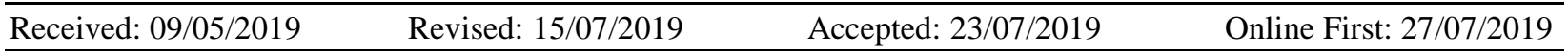

\section{Abstract}

The study was aimed to identify the physicochemical and sensory changes of strawberry and dates blend ready to serve drink in storage of three months with gap of 15 days at room temperature (25$\left.30{ }^{0} \mathrm{C}\right)$. Strawberry and dates juice blend ready to serve drink were formulated as $\mathrm{SDB}_{1}=9: 1$, $\mathrm{SDB}_{2}=8: 2, \mathrm{SDB}_{3}=7: 3, \mathrm{SDB}_{4}=6: 4$ and $\mathrm{SDB}_{5}=5: 5$ by addition of sodium benzoate $(0.01 \%)$ in each treatment as preservative and mixed $20 \%$ of each combination with $10^{\circ}$ brix sugar solution of calculated value. The samples were analyzed physicochemically ( $\mathrm{pH}$, vitamin $\mathrm{C}$, TSS, \% acidity, reducing sugar, non-reducing sugar and sugar acid ratio) as well as organoleptically (flavor, color, taste and overall acceptability). Outcomes of experiments showed a mean of total soluble solids of strawberry and dates blend ready to serve drink upgraded from 13.05 to $13.89^{\circ}$ brix. \% acidity of blend enhanced from 0.71 to 0.95 , reducing sugar increased from 9.29 to 10.91 , whereas $\mathrm{pH}$ was reduced from 4.66 to 3.82 , ascorbic acid value was declined from 48.67 to 31.51, non-reducing sugar decreased from 4.02 to 2.90 and sugar acid ratio declined from 20.23 to 14.77. Sensory evaluation showed that mean scores for color of strawberry and dates blend ready to serve drink were reduced from 8.36 to 5.10, flavor decreased from 8.15 to 5.21, taste reduced from 8.11 to 5.11 and overall acceptability also declined from 8.21 to 5.14 during storage. From this research it was concluded that $\mathrm{SDB}_{3}$ (Strawberry and date juice blend in ratio $(7: 3)+0.01 \%$ sodium benzoate) found finest among all other combinations of ready to serve drink.

Keywords: Juice blend; Organoleptically; Physicochemical; Ready to serve drink; Sodium benzoate

\section{Introduction}

Fruits are important source for good health, and good for all ages as it form an important part of healthy diet that's why natural compounds in foods and vegetables such as polyphenols, flavonoids and tannins have shown very promising results in fight against bacteria, fungus and viral infection [1]. Essential vitamins and polyphenolic compounds present in drinking fruit juices are related to ingestion of bioactive components. Different studies shown polyphnols in fruits 
are active agents against atherosclerosis, cancers, aging and inflammation [2].

Evidences shows 600 different types of dates on bases of their shape, size and appearances [3]. Date shows major portion of the diet in most of golf countries with minimum prices. In the Holy Quran dates are discussed in different occasions that show religious importance of dates for muslim. In the month of Ramadan usually Muslim breaks their day fasting with dates [4-6]. As Ahadith e Mubarak shows, "Poison and magic will not affect them who eat 7 ajwa dates at the start of day. (Sahih Bukhari Book 65, Hadith 356).

A high content of sugar in dates makes it nutritionally an energetic food [7]. Average energy of fresh and dried dates are 213 and 314 kcal/100 g respectively [8]. Vitamins also excessively present in date fruit [9]. The date fruit has antibacterial and antifungal properties so it is used against many infectious disorders [10]. Furthermore, antioxidant activity was found in aqueous extracts of dates, because they protect protein oxidation and having free radical scavenging capacity [11]. The fruit is solid, red fleshed and sweet, contains high amount of citric acid and small amount of malice acid. Anthocyanin pigment is responsible for the red color of the fruit. Flavor is due to presence of different volatile esters .By nutrition point of view strawberry fruit has low energy carbohydrate and high amount of vitamin $\mathrm{C}$ than oranges. Amount of Vitamin $\mathrm{C}$ in strawberry is $64.0 \mathrm{mg}$, fat $0.37 \mathrm{~g}$, fiber $2.3 \mathrm{~g}$ , calcium $14.0 \mathrm{mg}$, potassium $166.0 \mathrm{mg} / 160 \mathrm{~g}$, carbohydrate $7.02 \mathrm{~g}$, protein $0.61 \mathrm{~g}$ water 91.75 $\mathrm{g},, \mathrm{pH}$ varies from 3.27 to 3.86 , that keep its color. Amount of total acids ranges from 0.58 to $1.35 \%$. 8.0 to $11.5 \%$ soluble solids exists that is significant for market requirements [12]. Appealing color and pleasing flavor enhanced the requirement of juice of strawberry in the last ten years. But due to highly perishable fruit and a slight variation in temperature result in deterioration of strawberries [13]. Food industry considering new ingredients for developing new commercial food products. In this regard fruits of strawberry tree probably have appealing colors and better taste along with bioactive compounds. Recently different nutritious food products are being prepared by extraction of strawberry fruit like pastry fillings, yogurts, and pie, cereal and meat products [14].

In last few years demand of ready to serve drink has been increased. Blending is considered as one of the best methods to enhance the nutritional properties of the juice. Besides, natural health drink and appetizers can be made by mixing of 2 or more juices. Until now, strawberries and dates blend ready to serve drink has not studied therefore research was carried to prepare strawberry and dates blend ready to serve drink and a nutritious and energy rich product according to consumer taste and demand. Furthermore to study the effect of treatments and storage on physicochemical and sensory characteristics of product.

\section{Materials and methods}

This study carried out in the laboratory of Food Science and Technology Hazara Agriculture Research Station Abbottabad at room temperature $\left(25-30{ }^{0} \mathrm{C}\right)$ where physicochemical and sensory changes recorded in storage of strawberries and dates blend ready to serve drink for 90 days. Local market of Abbottabad was chosen to buy fresh strawberries and dates.

\section{Preparation of sample}

Strawberries and dates were purchased from the local fruit market of Abbottabad and were transported to the Food Technology laboratory of Hazara Agriculture Research Station where the research work was conducted. After washing diseased, damaged, bruised and immature fruits were discarded followed by dehulling (strawberries and dates), pitting (dates). Pulp was extracted by pulper and collected in container. Strawberry and date blends were prepared in different concentrations as 
mentioned in plan of study. $20 \%(50 \mathrm{ml})$ of each combination of blend were taken and mixed with $80 \%(200 \mathrm{ml})$ of $10^{0}$ Brix sugar solution to make volume up to $250 \mathrm{ml}$ for ready to serve drink.

\section{Packaging and storage of blend}

At room temperature in laboratory of Food Science and Technology Hazara Agriculture Research Station Abbottabad, transparent $250 \mathrm{ml}$ of glass bottles was used to keep strawberry and dates juice blend ready to serve drink for ninety days where physicochemical and sensory properties were measured by gap of fifteen days.

\section{Physicochemical analysis}

PH, Total Soluble Solids, \% Acidity, Ascorbic Acid, Ascorbic Acid, Reducing sugar and non- reducing sugar were measured by using the standard method of [15].

\section{Sensory evaluation}

Panel of 10 trained judge's investigated the sensory properties of samples of strawberry and date blend ready to serve drink for flavor, color, taste and overall acceptability. Panelists were requested to show their observations regarding sensory attributes by assigning the numbers by using a [16], 9 points hedonic scale that consist of (1-9) scores where 1 represented extremely dislike and 9 represented extremely liked. Readings of sensory properties were taken at 15 days difference in time of 3 months of storage.

\section{Statistical Analysis}

For statistical analysis, Complete Randomized Design (CRD) was used for data related with storage time period and samples. [17] Method of LSD test was used to discriminate means.

\section{Results}

\section{Physico-chemical analysis}

Initially value of $\mathrm{pH}$ for all treatments $\left(\mathrm{SDB}_{1}\right.$ to $\mathrm{SDB}_{5}$ ) of strawberry and date blended juice were found 4.52, 4,58, 4.65,4.74 and 4.83 which were slowly declined to 3.81 , $3.90,3.89,3.80$ and 3.71 respectively during three month of storage (Table 1). Mean of $\mathrm{pH}$ value appreciably decreased from 4.66 to 3.82. Least $\%$ declined in mean was found in $\mathrm{SDB}_{2}$ (14.85) followed by $\mathrm{SDB}_{1}$ (15.71) whereas highest \% reduced was found in $\mathrm{SDB}_{5}$ (23.19) followed by $\mathrm{SDB}_{4}$ (19.83). Least value of means were calculated in $\mathrm{SDB}_{1}$ (4.21) followed by $\mathrm{SDB}_{2}$ (4.28) whereas highest value of means were found in $\mathrm{SDB}_{3}$ (4.34) followed by $\mathrm{SDB}_{4}$ (4.34). Initially value of TSS for all treatments (SDB 1 to SDB 5) of strawberry and date blended juice were found 10.6, 12.2, 13.8, 15.4 and 17.1 which were slowly increased to 11.95 , 13.88, 15.92, 18.09 and 20.89 respectively during three month of storage. Mean of TSS value appreciably increased from 13.05 to 13.89. Least \% increase in mean was found in $\mathrm{SDB}_{1}(11.24)$ followed by $\mathrm{SDB}_{2}(12.85)$ whereas highest \% increase was found in $\mathrm{SDB}_{5}$ (18.13) followed by $\mathrm{SDB}_{4}$ (16.30). Least value of means were calculated in $\mathrm{SDB}_{1}$ (12.74) followed by $\mathrm{SDB}_{2}$ (13.77) whereas highest value of means were found in $\mathrm{SDB}_{5}$ (22.16) followed by $\mathrm{SDB}_{4}(17.47)$. Initially value of titrable acidity for all treatments $\left(\mathrm{SDB}_{1}\right.$ toSDBSDB 5$)$ of strawberry and date blended juice were found $0.86,0.78,0.68,0.56$ and 0.48 which were slowly increased to $1.2,1.08,0.95,0.8$ and 0.71 respectively during three month of storage. Mean of titrable acidity value appreciably increased from 0.71 to 0.95 . Least \% increase in mean was found in $\mathrm{SDB}_{5}$ (0.58) followed by $\mathrm{SDB}_{4}$ (0.66) whereas highest \% increase was found in $\mathrm{SDB}_{1}(1.01)$ followed by $\mathrm{SDB}_{2}(0.92)$. Least value of means were calculated in $\mathrm{SDB}_{2}$ (38.46) followed by $\mathrm{SDB}_{1}$ (39.53) whereas highest value of means were found in $\mathrm{SDB}_{5}$ (47.92) followed by $\mathrm{SDB}_{4}$ (42.86). Initially value of ascorbic acid for all treatments $\left(\mathrm{SDB}_{1}\right.$ to $\mathrm{SDB}_{5}$ ) of strawberry and date blended juice were found 59.54,56.14, 51.6, 42.93 and 33.12 which were slowly declined to $39.51,35.32, \quad 35.01, \quad 26.62$ and 18.81 
respectively during three month of storage. Mean of ascorbic acid value appreciably decreased from 48.67 to 31.51. Least \%declined in mean was found in $\mathrm{SDB}_{5}$ (26.18) followed by $\mathrm{SDB}_{4}$ (34.53) whereas highest \% reduced was found in $\mathrm{SDB}_{1}$ (49.88) followed by $\mathrm{SDB}_{2}$ (45.08). Least value of means were calculated in $\mathrm{SDB}_{3}$ (32.15) followed by $\mathrm{SDB}_{1}$ (33.64) whereas highest value of means were found in $\mathrm{SDB}_{5}$ (40.19) followed by $\mathrm{SDB}_{4}$ (37.19). Initially value of reducing sugar acidity for all treatments $\left(\mathrm{SDB}_{1}\right.$ to $\left.\mathrm{SDB}_{5}\right)$ of strawberry and date blended juice were found 7.33, 8.18, 9.24, 16.43 and 11.26 which were slowly increased to $8.18,9.22,10.58,12.58$ and 13.98 respectively during three month of storage. Mean of reducing sugar value appreciably decreased from 9.29 to 10.91 . Least \% increase in mean was found in $\mathrm{SDB}_{1}$ (7.66) followed by $\mathrm{SDB}_{2}$ (8.59) whereas highest \% increase was found in $\mathrm{SDB}_{5}$ (11.89) followed by $\mathrm{SDB}_{4}$ (10.95). Least value of means were calculated in $\mathrm{SDB}_{1}$ (11.6) followed by $\mathrm{SDB}_{2}$ (12.71) whereas highest value of means were found in $\mathrm{SDB}_{5}$ (24.16) followed by $\mathrm{SDB}_{4}$ (20.61). Initially value of non-reducing sugar for all treatments $\left(\mathrm{SDB}_{1}\right.$ to $\left.\mathrm{SDB}_{5}\right)$ of strawberry and date blended juice were found 2.77, 3.09, $3.86,4.17$ and 4.98 which were slowly declined to $2.42,2.56,3.25,3.48$ and 4.01 respectively during three month of storage. Mean of non-reducing sugar value appreciably decreased from 4.02 to 2.90 . Least \%declined in mean was found in $\mathrm{SDB}_{1}$ (2.63) followed by $\mathrm{SDB}_{2}$ (2.86) whereas highest \% reduced was found in $\mathrm{SDB}_{5}(4.65)$ followed by $\mathrm{SDB}_{4}$ (3.89). Least value of means were calculated in $\mathrm{SDB}_{1}$ (12.64) followed by $\mathrm{SDB}_{2}$ (14.95) whereas highest value of means were found in $\mathrm{SDB}_{5}(19.48)$ followed by $\mathrm{SDB}_{4}$ (16.55). Initially value of sugar acid ratio for all treatments $\left(\mathrm{SDB}_{1}\right.$ to $\mathrm{SDB}_{5}$ ) of strawberry and date blended juice were found 12.33, 15.64, 20.29, 27.5 and
35.63 which were slowly declined to 9.96 , $12.85,16.76,22.61$ and 35.63 respectively during three month of storage. Mean of sugar acid ratio value appreciably decreased from 20.23 to 14.7 . Least \%declined in mean was found in $\mathrm{SDB}_{1}$ (11.17) followed by $\mathrm{SDB}_{2}$ (14.10) whereas highest \% reduced was found in $\mathrm{SDB}_{5}$ (30.79) followed by $\mathrm{SDB}_{4}$ (24.72). Least value of means were calculated in $\mathrm{SDB}_{4}$ (17.78) followed by $\mathrm{SDB}_{3}$ (17.82) whereas highest value of means were found in $\mathrm{SDB}_{5}$ (26.68) followed by $\mathrm{SDB}_{3}$ (20.61).

\section{Organoleptic analysis}

Initially value of flavor for all treatments $\left(\mathrm{SDB}_{1}\right.$ to $\left.\mathrm{SDB}_{5}\right)$ of strawberry and date blended juice were found $8.24,8.45,8.59$, 7.95 and 7.51 which were slowly declined to $4.92,6.28,6.67,4.34$ and 3.86 respectively during three month of storage (Table 2). Mean of flavor value appreciably decreased from8.15 to 5.21. Least \%declined in mean was found in $\mathrm{SDB}_{5}(6.15)$ followed by $\mathrm{SDB}_{4}$ (6.60) whereas highest \% reduced was found in $\mathrm{SDB}_{3}$ (22.35) followed by $\mathrm{SDB}_{2}$ (25.68). Least value of means were calculated in $\mathrm{SDB}_{3}$ (22.35) followed by $\mathrm{SDB}_{2}$ (25.68) whereas highest value of means were found in $\mathrm{SDB}_{5}$ (48.6) followed by $\mathrm{SDB}_{4}$ (45.41). Initially value of color for all treatments $\left(\mathrm{SDB}_{1}\right.$ to $\left.\mathrm{SDB}_{5}\right)$ of strawberry and date blended juice were found 8.59, 8.28, 8.59, 8.14 and 8,18 which were slowly declined to $4.92,6.17,6.75,4.13$ and 3.54 respectively during three month of storage. Mean of color value appreciably decreased from8.36 to 5.10 . Least \%declined in mean was found in $\mathrm{SDB}_{5}$ (6.42) followed by $\mathrm{SDB}_{4}$ (6.60) whereas highest $\%$ reduced was found in $\mathrm{SDB}_{3}$ (7.79) followed by $\mathrm{SDB}_{2}$ (7.26). Least value of means were calculated in $\mathrm{SDB}_{3}$ (21.42) followed by $\mathrm{SDB}_{2}$ (25.48) whereas highest value of means were found in $\mathrm{SDB}_{5}$ (56.72) followed by $\mathrm{SDB}_{4}$ (49.26). Initially value of taste for all treatments $\left(\mathrm{SDB}_{1}\right.$ to $\mathrm{SDB}_{5}$ ) of strawberry and date blended juice 
were found 8.12, 8.47, 8.53, 7.91 and 7.54 which were slowly declined to $4.74,6.39$, $6.65,4.24$ and 3.51 respectively during three month of storage. Mean of taste value appreciably decreased from8.11 to 5.11. Least \%declined in mean was found in $\mathrm{SDB}_{5}$ (6) followed by $\mathrm{SDB}_{4}$ (6.47) whereas highest $\%$ reduced was found in $\mathrm{SDB}_{3}$ (7.63) followed by $\mathrm{SDB}_{2}$ (7.50). Least value of means were calculated in $\mathrm{SDB}_{3}$ (22.04) followed by $\mathrm{SDB}_{2}$ (24.56) whereas highest value of means were found in $\mathrm{SDB}_{5}(53.45)$ followed by $\mathrm{SDB}_{4}$ (46.4). Initially value of overall acceptability for all treatments $\left(\mathrm{SDB}_{1}\right.$ to $\mathrm{SDB}_{5}$ ) of strawberry and date blended juice were found $8.32,8.4,8.57,8$ and 7.74 which were slowly declined to $4.86,6.28$, $6.69,4.24$ and 3.64 respectively during three month of storage. Mean of overall acceptability value appreciably decreased from8.21 to 5.14. Least \%declined in mean was found in $\mathrm{SDB}_{5}(6.18)$ followed by $\mathrm{SDB}_{4}$ (6.55) whereas highest \% reduced was found in $\mathrm{SDB}_{3}$ (7.67) followed by $\mathrm{SDB}_{2}(7.40)$. Least value of means were calculated in $\mathrm{SDB}_{3}$ (21.9) followed by $\mathrm{SDB}_{2}$ (25.2) whereas highest value of means were found in $\mathrm{SDB}_{5}$ (53) followed by $\mathrm{SDB}_{4}$ (47).

\section{Discussion}

\section{Physico-chemical analysis}

Study concluded that there is a significant $(\mathrm{P}$ $<0.05$ ) effect of treatments and storage intervals on $\mathrm{pH}$ of strawberry and dates blended juice (Table 1) (Figure 1). Hydrolysis of pectic and free acids or formation of acidic components may cause reduction in $\mathrm{pH}$ value and increases acidity during storage [18] Outcomes were in agreement with recordings of [19] who showed (3.64 - 3.22) reduction trend in $\mathrm{pH}$ value of mixed fruit jam of pear and apple fruit. Identical results also recorded by [20] who concluded on dropping in $\mathrm{pH}$ from (3.97-2.94) of apricot and apple juice blend at storage duration. Results concluded a significant $(\mathrm{P}<0.05)$ effect of treatments and storage intervals on TSS of strawberry and dates juice blend. Hydrolysis of di and poly saccharides to mono saccharides may cause mixing of fruit components result in increase in total soluble solids during storage. The increase is believed to occur presumably due to conversion of some of the insoluble portion (sucrose in cell membrane or blood stream) into soluble fraction(glucose and fructose that can soluble in cell membrane and blood stream) throughout the storage. The outcome matches with the results of [21] who stated increase in total soluble solids of mango and sea-buckthorn juice blend from (16.15 to $18.50 \%$ ) in storage period. Kinnow, pomegranate and ginger blended juice also showed an increase in total soluble solids (12.00-14.13\%) in research of Bhardwaj and Mukherjee (2010) for six month storage at room temperature. Similarly (15 to $15.3 \%$ ) raised in TSS of grass Valencia orange, Egyptian lime and cantaloupe blended juice were found by [22]. The elevating trend in titrable acidity might be the result of oxidation or destruction of reducing sugars or development of acidic compounds existing in juice. Increasing trend may also be the cause of breakdown of sugars to caroboxylic acids. Increase in titrable acidity may be due to the breakdown of pectin into pectinic acid or due to the formation of acid by the breakdown of polysaccharides or oxidation of reducing sugars [23]. Raised in titrable acidity (0.60 to $0.78 \%$ ) were also shown by [24] in his research of mixed fruit jam of apple and pear fruit during storage. Similar outcomes (0.29$0.32 \%$ ) in titrable acidity were also revealed by [25]. These results also matches with the results of [26] in time period of analyzing fruit juices during storage. Processing, storage time and exposure to light might result in decreasing of ascorbic acid contents. It was also concluded that might be due to presence of oxygen in the headspace of the package and product declines ascorbic acid contents by [27]. The reducing in ascorbic acid at the time of storage may be due to 
oxidation of ascorbic acid to dehydro ascorbic acid and after that to 2,3diketogluconic acid [28]. These conclusions similar to results of [28] who recorded the decline in ascorbic acid from (45.43 to $31.76 \mathrm{mg} / 100 \mathrm{~g}$ ) of blend of mango and sea-buckthorn juice at the time of storage. Related outcomes was noticed by [27] who revealed that ascorbic acid decline from (17.40 to $9.19 \mathrm{mg} / 100 \mathrm{~g}$ ) in mixed fruit jam of apple and apple throughout storage. Same conclusion describe by [29] who stated that blend of Kinnow, Pomegranate and jinger juice (87: 10: 3) lost ascorbic acid from 18.38-12.90 $\mathrm{mg} / 100 \mathrm{ml}$ in six month storage at $25-30{ }^{\circ} \mathrm{C}$. The significant increasing trend were recorded in reducing sugar may be because of sucrose inversion to reducing sugar (glucose+fructose) or may be due to duration of storage period. These results matches with outcomes of [27] who revealed that reducing sugar increases (6.58 to $6.99 \%$ ) in storage of blend of apple and apricot juice. Same results recorded by [29] and stated (6.61-7.70\%) increase in reducing sugar in his research. According to [27] he also noticed an inclination in reducing and total sugars contents at the time of storage. As a result of [23] research he revealed a linear increase in reducing sugar of mango pulp in his 90 days storage study. The decreasing trend in nonreducing sugar may be te result of inversion of non-reducing sugar to reducing sugar, raised in acidity and duration of storage. These outcomes confirmed by [21] who showed $(6.86-4.35 \%)$ decreasing trend of non-reducing sugars in blend of mango and sea-buckthorn juice at the time of storage. Similar observations $(2.61-1.96 \%)$ revealed by [17] where he reported decrease in non-reducing sugars in blend of apple and apricot juice that was preserved by sodium benzoate in refrigerated conditions. Decreasing values in TSS/TA ratio may be due to long duration of storage that raises the sweetness of the product. Same results revealed by [6], who determined decreasing aptitude in sugar acid ratio (20.15-18.25) throughout apple pulp storage. According to [12], he showed decline (24.45-21.35) in sugar acid ratio of apple pulp at the time of storage study.

Table 1. Physicochemical Analysis of strawberry and date blended juice

\begin{tabular}{|c|c|c|c|c|c|c|c|}
\hline Treatments & PH & TSS & $\begin{array}{c}\text { Titratable } \\
\text { Acidity }\end{array}$ & Ascorbic acid & $\begin{array}{c}\text { R- } \\
\text { Sugars }\end{array}$ & $\begin{array}{c}\text { Non- R- } \\
\text { Sugars }\end{array}$ & $\begin{array}{c}\text { S-A- } \\
\text { Ratio }\end{array}$ \\
\hline $\mathrm{SDB}_{1}$ & $4.21 \mathrm{a}$ & $11.24 \mathrm{a}$ & $1.01 \mathrm{a}$ & $49.88 \mathrm{a}$ & $7.66 \mathrm{a}$ & $2.63 \mathrm{a}$ & $11.17 \mathrm{a}$ \\
\hline $\mathrm{SDB}_{2}$ & $4.28 \mathrm{ab}$ & $12.85 \mathrm{~b}$ & $0.92 \mathrm{~b}$ & $45.08 \mathrm{~b}$ & $8.59 \mathrm{~b}$ & $2.86 \mathrm{~b}$ & $14.10 \mathrm{~b}$ \\
\hline $\mathrm{SDB}_{3}$ & $4.34 \mathrm{ab}$ & $14.59 \mathrm{c}$ & $0.79 \mathrm{c}$ & $43.97 \mathrm{c}$ & $9.67 \mathrm{c}$ & $3.58 \mathrm{c}$ & $18.59 \mathrm{c}$ \\
\hline $\mathrm{SDB}_{4}$ & $4.34 \mathrm{bc}$ & $16.30 \mathrm{~d}$ & $0.66 \mathrm{~d}$ & $34.53 \mathrm{~d}$ & $10.95 \mathrm{~d}$ & $3.89 \mathrm{~d}$ & $24.72 \mathrm{~d}$ \\
\hline $\mathrm{SDB}_{5}$ & $4.37 \mathrm{c}$ & $18.13 \mathrm{e}$ & $0.58 \mathrm{e}$ & $26.18 \mathrm{e}$ & $11.89 \mathrm{e}$ & $4.65 \mathrm{e}$ & $30.79 \mathrm{e}$ \\
\hline
\end{tabular}

Mean followed by unmatched alphabet are significantly $(\mathrm{P}<0.05)$ different from each other where stands for SDB $=$ Strawberry Date Blended 


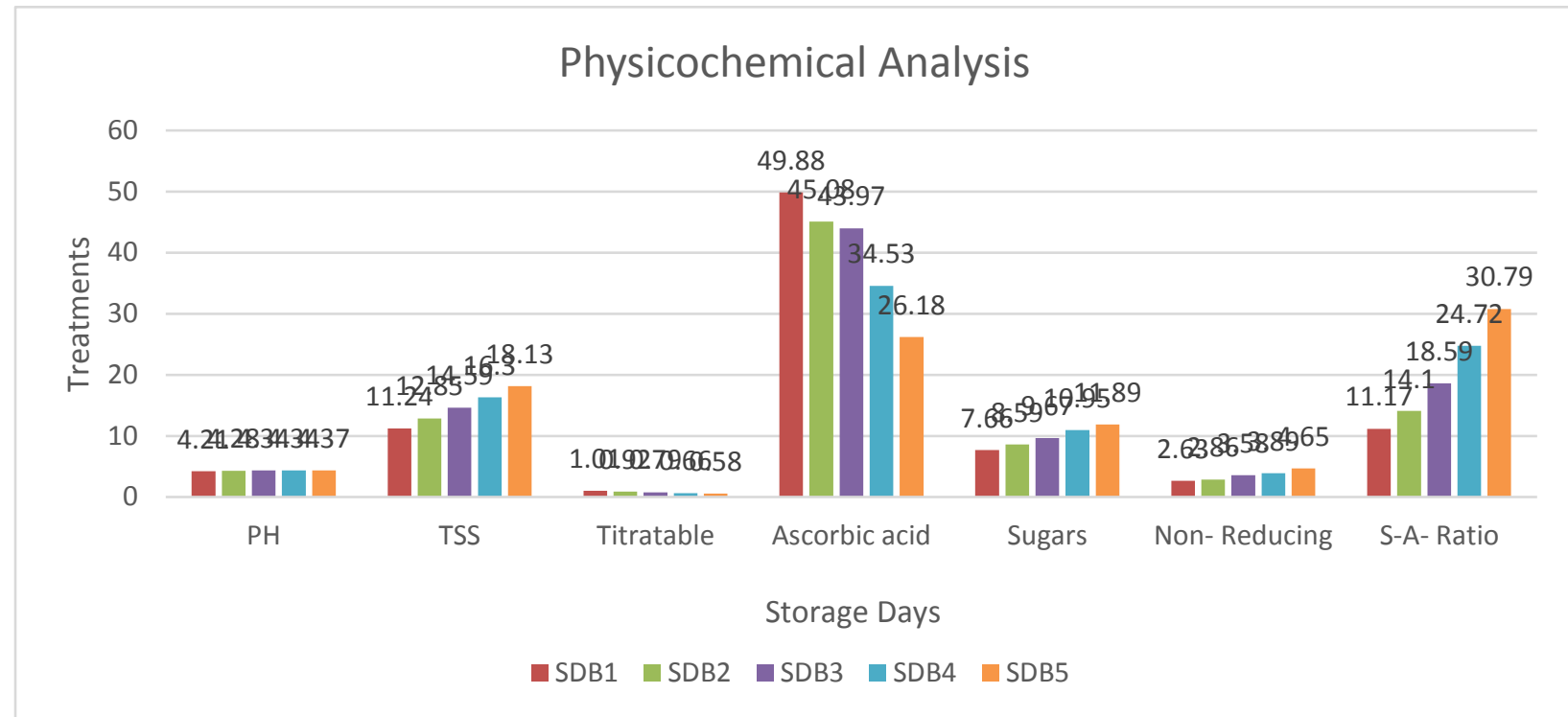

Figure 1. Shows mean values of physicochemical analysis of strawberry and date blended juice

\section{Organoleptic analysis}

During storage the reduction in flavor contents may be because of alteration in volatile compounds of the blend (Table 2) (Figure 2). Varying in volatile compounds in blend may result loss in flavor throughout storage. These results confirms by outcomes of [17] who revealed decline (8.8-3.7) in sensory parameters in blend of apple and apricot throughout storage. Results of [19] also shown loss in flavoring score from 8.005.00 . The reduced in color may be because of enzymatic browning caused by reaction between amino acids and reducing sugars, hasten by increasing temperature, oxidation of phenolic compounds and formation of dehydro-ascorbic acid from ascorbic acid at the time of storage [30]. These outcomes confirmed by [18] who shown a decline (8.23.2) in blend of orange and carrot juice. According to [13] he noticed loss in color during his research on storage study of Guava and Sapota pulp blended jam. The decline in taste attributes may be because of temperature, time and duration of storage of product. The decrease in taste occurs may be as a result of conversion of ascorbic acid and furfural production along with oxidative and different deteriorative reactions happening in the product at the time of its storage [28]. Similar outcomes recorded by [18] who revealed a decline (8.3-4.3) in blend of orange and carrot juice. The decline in overall acceptability may be because of increase in storage time and rise in temperature that leads to major degradation, which results in reduction in overall acceptability. These findings confirmed by results of [17] who stated the loss from (7.31-3.24) in overall properties of blend of apple and apricot juice. These results are similar with [29] research outcomes conducted on phalsa nectar and squash, study on jack fruit ready to serve beverage by [23] and research on tamarind ready to serve beverage by [22]. 
Table 2. Organoleptic Analysis of strawberry and date blended juice

\begin{tabular}{|c|c|c|c|c|}
\hline Treatments & Flavor & Color & Texture & Overall Acceptability \\
\hline $\mathrm{SDB}_{1}$ & $7.09 \mathrm{~b}$ & $7.01 \mathrm{bc}$ & $6.58 \mathrm{~b}$ & $6.89 \mathrm{~b}$ \\
\hline $\mathrm{SDB}_{2}$ & $7.45 \mathrm{a}$ & $7.26 \mathrm{~b}$ & $7.50 \mathrm{a}$ & $7.40 \mathrm{a}$ \\
\hline $\mathrm{SDB}_{3}$ & $7.63 \mathrm{a}$ & $7.79 \mathrm{a}$ & $7.63 \mathrm{a}$ & $7.67 \mathrm{a}$ \\
\hline $\mathrm{SDB}_{4}$ & $6.60 \mathrm{c}$ & $6.60 \mathrm{~cd}$ & $6.47 \mathrm{c}$ & $6.55 \mathrm{bc}$ \\
\hline $\mathrm{SDB}_{5}$ & $6.15 \mathrm{~d}$ & $6.42 \mathrm{~d}$ & $6.00 \mathrm{~d}$ & $6.18 \mathrm{c}$ \\
\hline
\end{tabular}

Mean followed by unmatched alphabet are significantly $(\mathrm{P}<0.05)$ different from each other

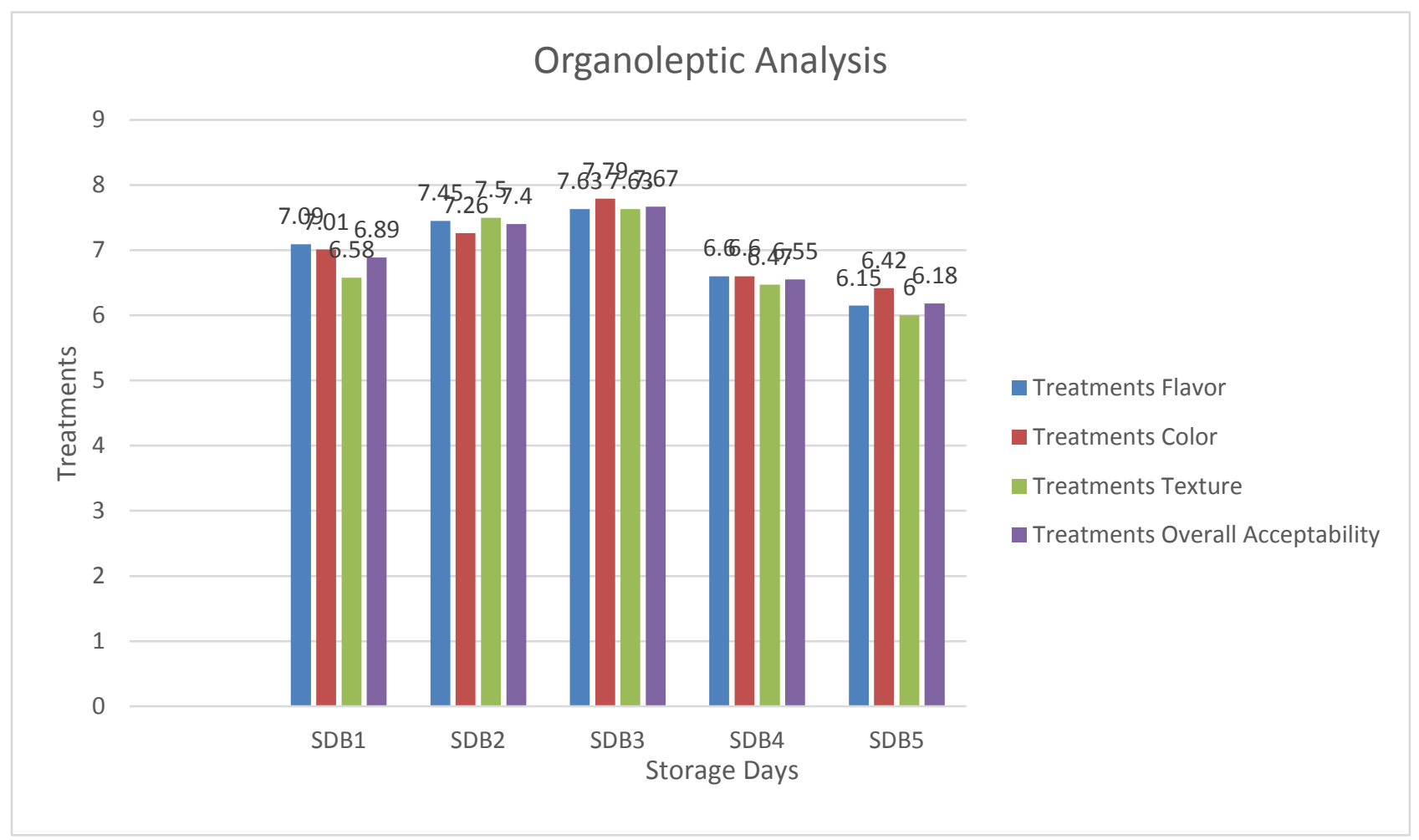

Figure 2. Shows mean values of organoleptic analysis of strawberry and date blended juice

\section{Conclusion}

This study concluded that changes were found in physiochemical and sensory properties whose results showed that $\mathrm{SDB}_{3}$ (strawberry and date juice blend ratio $(7: 3)+$ $0.1 \%$ sodium benzoate) got highest scores for sensory characteristics followed by $\mathrm{SDB}_{2}$ (strawberry and date juice blend ratio $(8: 2)+$ $0.1 \%$ sodium benzoate). During three months of storage a linear decrease was recorded for
$\mathrm{pH}$, ascorbic acid, non-reducing sugar, sugar acid ratio, flavor, color, taste and overall acceptability whereas increase was observed in TSS, titrable acidity and reducing sugar.

\section{Authors' contributions}

Conceived and designed the experiments: $\mathrm{M}$ Khalid, A Muhammad \& M Ayub, Performed the experiments: M Khalid, B Shamraiz \& SA Ali, Analyzed the data: M Muneeb \& Y Durrani, Contributed materials/ 
analysis/ tools: M Khalid \& M Muneeb, Wrote the paper: M Muneeb.

\section{References}

1. Assous MTM, Waseif KHM \& Gado GBA (2012). Production and evaluation of nontraditional products from lemon grass. Egypt J Agri Res 91(1): 205-212.

2. AOAC (2012). Official method of analysis. The Assoc. Official Analytical Chemists $19^{\text {th }}$ Ed. Arlington USA.

3. Asad A and Durrani Y (2009). Physicochemical response of apple pulp to chemical preservatives during storage. MSc Thesis Dept. of Food Sci. and Tech. KPK Agri Uni Peshawar.

4. Ayub M, Ullah J, Muhammad A \& Zeb A. (2009). Evaluation of strawberry juice preserved with chemical preservatives at refrigeration temperature. Inter $J \mathrm{Nutr}$ And Metabolism 2(2): 27-032.

5. Baliga S, Baliga V \& Kandathil S. (2011). A review of the chemistry and pharmacology of the date fruits (Phoenix dactylifera L.). Food Res Inter 44: 18121822.

6. Bhardwaj RL \& Mukherjee S (2012). Factors affecting physico-chemical, sensory and microbiological quality of kinnow juice blends. J Nutr Food Sci 2(6): 1-7.

7. Durance NR \& Lewinsohn E (1986). Physicochemical characteristics and storage behavior of apple. Dept. of Food Sci. Ben Gurion Univ of The Negev, Beersheva, Israel.

8. Er Patil MM, Kalse ESB \& Sawant AA (2013). Prepration of guava jam blended with sapota. Agri Engg Inter CIGR J 15(1): 177-172.

9. Farsi MA \& Lee CY (2008). Optimization of phenolics and dietary fibre extraction from date seeds. $J$ of Food Chem 108: 977-985.

10. Ganhao R, Morcuende D \& Estevez. (2010). Protein oxidation in emulsified cooked burger patties with added fruit extracts: Influence on colour and texture deterioration during chill storage. Meat Sci 85(3): 402-409.

11. Gilani SN (2002). Development of mango squash from four different cultivars of mango. M.Sc. Thesis. Agri Uni Peshawar.

12. Hussain I, Zeb A \& Ayub M (2011). Evaluation of apple and apricot blend juice preserved with sodium benzoate at refrigeration temperature. World J Dairy \& Food Sci 6(1): 79-85.

13. Jain SK \& Khurdiya DS (2004). Vitamin $\mathrm{C}$ enrichment of fruit juice based ready to serve beverages through blending of Indian gooseberry (EmblicaofficinalisGaertn) juice. Plant food for Hum Nutri 59: 63-66.

14. Jain S, Sankhla APK, Dashora A \& Sankhla AK (2003). Physicochemical and sensory analysis of orange drink. $J$ Food Scci Tech India 40(6): 656-659.

15. Khan R, Afridi SR, Ilyas M, Abid H, Sohail M \& Khan SA (2012). Effect of different chemical preservatives on the storage stability of mango-sea buckthorn blended juice. Pak J Biochem Mol Biol 45(1): 6-10.

16. Kotecha PM \& Kadam SS (2003). Preparation of ready to serve beverage, syrup and concentrate from tamarind. $J$ Food Sci and Techn 40: 76-79.

17. Krishnaveni A, Manimegalai G \& Savavanakumar R (2001). Storage stability of jack fruit (AtrocarpusheterophyllusL.) RTS beverage. J Food Sci and Technol 38: 601-602.

18. Larmond E (1977). Laboratory methods of sensory evaluation of foods. Canada Deptt Agric 128(4): 27-37.

19. Leja M, Kaminska R, Kramer M, Kaul AM \& Carle A (2013). The content of phenolic compound and redical scavenging activity varies with carrot 
origion and root color. Plant Foods for Human Nutri 68(2): 163-170.

20. Mehmood Z, Zeb A, Ayub M, Bibi N, Badshah A \& Ihsanullah (2008). Effect of Pasteurization and Chemical preservativeson the Quality and shelf stability of Apple Juice. Amer J Food Technol 3(2): 147-153.

21. Mir S A, Wani S M, Ahmad M, Wani T A, Gani A, Mir SA \& Masoodi FA (2015). Effect of packaging and storage on the physicochemical and antioxidant properties of quince candy. J Food Sci and Tech 52: 7313-7320.

22. Muzzaffar S, Jan R, Wani IA, Masoodi FA, Bhat MM, Wani TA \& Wani GR (2016). Effect of preservation methods and storage period on the chemical composition and sensory properties of strawberry crush. J Cogent Food \& Agric 2: 1-11.

23. Raj D, Sharma PC \& Vaidya D (2011). Effect of blending and storage on quality characteristics of blended sand pearapple juice beverage. J Food Sci Tech 48(1): 102-105.

24. Rosnah S, W Wong, M Noraziah \& H Osman (2012). Chemical composition changes of two water apple. Inter $J$ of Food Res 19(1): 167-17.
25. Shakir I, Durrani Y, Hussain I, Qazi I M \& Zeb A (2008). Physicochemical analysis of apple and pear mixed fruit jam prepared from varities grown in Azad Jammu and Kashmir. Pak J Nutrition 7(1): 177-180.

26. Shimoda M \& Osajima Y (1981). Studies on off-flavour formed during storage of Satsuma mandarin juice. $J$ Agric Chem Soc of Japan 55(6): 471476.

27. Steel R \& Torrie J (1997). Principal and procedure of statistics (2008). A biomaterical approach, $3^{\text {rd }}$ Ed., McGraw Hill Book Co. NY. USA.

28. Vayalil PK (2002). Antioxidant and antimutagenic properties of aqueous extract of date fruit (Phoenix dactylifera L. Arecaceae). J Agric Food Chem 50(3): 610-617.

29. Waskar DP \& Khurdiya DS (1987). Processing and storage of phalsa beverages. Indian Food Packer 41: 7-16.

30. Wisal S, Zeb A, Ayub M \& Ihsanullah (2013). Refrigeration storage studies of strawberry juice with Tss of 7.5 and 20.5 Obrix treated with sodium benzoate and potassium sorbate. Sarhad J of Agric 29: 433-439. 